\title{
Business process management and digital transformation in higher education
}

Jeannie Pridmore, University of West Georgia,jpridmor@westga.edu Joy Godin, Georgia College and State University, joy.godin@gcsu.edu

\begin{abstract}
Business Process Management (BPM) is critical for organizations to be competitive. Organizations need employees with BPM knowledge and skills. Implementing BPM curriculum in higher education has been occurring over the last couple of decades. Due to Covid-19 causing higher education institutions to shut down face-to-face operations, it was crucial to develop instructional methods that would virtually allow effective teaching of BPM. This paper presents a digitally transforming paper game simulation method to teach business process integration and business process management. Overall, the students reported high levels of learning using the digitally transformed teaching method.
\end{abstract}

Keywords: Digital Transformation, Business Process Management, Enterprise Resource Planning, Higher Education

\section{Introduction}

Digital transformation is the integration of technology into areas of a business resulting in fundamental changes to how the business functions and how they deliver value to customers (Baiyere et al., 2020). Covid-19 forced organizations, including higher education, to rapidly embrace digital transformation. However, implementing digital transformations has been challenging. It is estimated that less than $30 \%$ of digital transformations are successful in industry (McKinsey, 2018).

Business Process Management (BPM) has emerged as an effective management strategy and an efficient technology management strategy for implementing technological solutions for managing cross-functional business processes. BPM is a structured approach to analyze fundamental activities and support continual improvement in areas such as manufacturing, marketing, communications, and other major elements of a company's operations (Zairi, 1997). BPM is a complex topic that focuses on the main facets of business operations where there is a large amount of added value and has emerged as an effective management strategy over the last couple of decades (Pasha, 2012).

Previous research has suggested that BPM is critical for organizations to be competitive and to achieve their strategic goals (Sarvepalli \& Godin, 2017; Hadidi, 2014; Bandara et al., 2010). For the last decade, organizations using BPM have increased due to increased Enterprise Resource Planning (ERP) systems implementations. In addition, BPM has also been linked to organizations delivering successful digital transformation (Baiyere et al., 2020).

Previous research has suggested that organizations need employees with knowledge of BPM (Sarvepalli \& Godin, 2017), and in 2020, the need for BPM knowledge to support digital transformation became critical. However, the lack of BPM knowledge and skills has been reported as an organizational problem (Pasha, 


\section{Issues in Information Systems}

Volume 22, Issue 4, pp. 180-190, 2021

2012). With BPM becoming increasingly more important in industry, incorporating BPM curriculum in higher education is necessary. BPM is a complex topic to teach and is traditionally taught in a face-to-face learning environment. Due to Covid-19 shutting down face-to-face learning, higher education had to go through its own digital transformation. Therefore, reimagining how to teach BPM in a digital environment became a crucial task.

This paper presents a structured methodology for how to teach BPM in a virtual environment. First, we will review the literature on teaching BPM, simulations in higher education and explain the paper game simulation. Next, we will present the methods and virtual platforms used. Then we will present our results and findings.

\section{Teaching business process management}

Over the last couple of decades, BPM has made strides in academia, specifically in areas such as Information Systems, Operations Management, and Computer Science (Bandara et al., 2010). Previous research has stressed the importance of teaching BPM (Sarvepali \& Godin, 2017). However, higher education by design focuses on functional knowledge rather than cross-functional business expertise, which can lead to difficulties in integrating BPM into the curriculum (Bandara, et al., 2010; Pasha, 2012). Using Enterprise Resource Planning concepts to teach BPM has been seen as a successful design (Sarvepali \& Godin, 2017). Extending the work of Sarvepali \& Godin (2017), who used the ERP Paper Game simulation to teach ERP and BPM, the decision was made to digitally transform the Paper game simulation to teach BPM virtually.

\section{Simulations and the paper game}

Active learning methods such as simulations have been given a lot of attention in higher education. Previous research has identified the value of using games with and without technology in the classroom (Bowen, 2012; Sheldon, 2011). Simulation games are believed to be effective pedagogical techniques (Pridmore \& Godin, 2018; Lean, et al., 2006; Russ \& Drury-Grogan, 2013; Newell, 2004; Auman, 2011; Leger et al., 2011; Gredler, 2004; Hough, 2012; Hays, 2008; Smith \& Smith, 2008; Salas, Wildman, \& Piccolo, 2009; Hartman et al., 2013; Vos, 2014). In addition, students who participated in class simulations reported high levels of classroom engagement (Auman, 2011). Simulation games have been classified into two categories: computer-based games and non-computer-based games.

Simulation games have been used extensively to teach integrated business processes and ERP concepts and BPM (Adelsberger et al., 1999; Pridmore \& Godin, 2018; Saraswat, Anderson, \& Chircu, 2014). For example, in one study, researchers have used a 'Business Simulation Project' within an ERP fundamentals course to teach the integration of business processes found that the game accelerates learning and allows participants to apply decision-making skills (Cronan et al., 2011). In another study, Cronan \& Douglas (2012) found that students who participated in simulation reported a better understanding of integrated business processes.

The Paper Game simulation (Leger, 2006; Leger, 2015) was developed by HEC Montreal, a French College of Business in Montreal, Quebec, to teach basic business processes to students with limited experience as a preparatory step for the ERPSim game. While playing the Paper Game, students practice running an organization's core business processes: buying, producing, and selling. They are also introduced to accounting transactions that support each of the core processes. The game is simple and does not require IT support or technology. The necessary materials are flip charts, post-it notes in five different colors, two sheets of light-colored paper, dice, and scissors. Students are divided into teams. Each team manages a 


\section{Issues in Information Systems}

Volume 22, Issue 4, pp. 180-190, 2021

manufacturing company that purchases sheets of paper (raw materials) from suppliers. Next, the paper is cut into squares (finished goods) and sold to customers. Finally, they must make payments to the suppliers and receive payments from customers. The instructor plays both customer and supplier roles, and teams must internally decide how to perform their tasks.

At the start of each turn, the instructor rolls the dice. The numbers on the dice represent the price the customer will pay for the final product. Each team is free to sell as many pieces as they have in inventory, and to indicate interest to sell, one student per team must indicate the amount sold on an orange post-it (Sales Order).

Next, one student per team must bring a blue-post it (invoice) with the quantity sold, the price, and the amount owed by the customer and place it in the instructor's customer account matrix (see Table 1 for an example of the supplier and customer matrix) during $\mathrm{T}+2$ (which represents the current round plus two additional rounds). This is done because the term of payment from the customer is in 2 rounds. Finally, a student must return two turns later to receive payment from the instructor on a white post-it (client check).

Then the instructor throws the supplier dice to determine the cost of buying paper. The paper will serve as the raw materials needed to produce the finished goods. One student per team must indicate the desired quantity and price on a pink post-it (purchase order) to indicate interest in buying. The student must place the pink Post-it in the purchasing matrix at $\mathrm{T}+1$ because delivery is made 1 round later. Payment must be made during delivery, so the student must write the purchase amount on a green Post-it note (pay the vendor, i.e., the company check). After completing half of the rounds, students are given time to reflect on the business processes. At the end of the game, they must be able to report their accounting and inventory information.

The Paper Game simulation is an active in-person simulation. To digitally transform it, we had to reimage how the collaboration could be done virtually and how each step in the simulation could be done virtually. The first decision made was to use Zoom for the class and for team collaboration due to Zoom's functionality of breakout rooms. Next, Mural was chosen to be used as the virtual collaboration whiteboard space. Mural is a web-based visual collaboration space where people can work virtually in real-time, communicate visually using sticky notes, flowcharts, drawings, and includes a built-in timer and voting capabilities. The students used virtual sticky notes in Mural to post the buying, selling, and to record their accounting documents. The Mural boards created for the customer whiteboard and the supplier whiteboard used in the simulation are displayed in Figures 1 and 2. The instructors used virtual dice to roll to determine the price of finished goods and the price of raw materials. Figure 3 shows the completed Mural boards at the end of one class period of the simulation. 


\section{Issues in Information Systems}

Volume 22, Issue 4, pp. 180-190, 2021

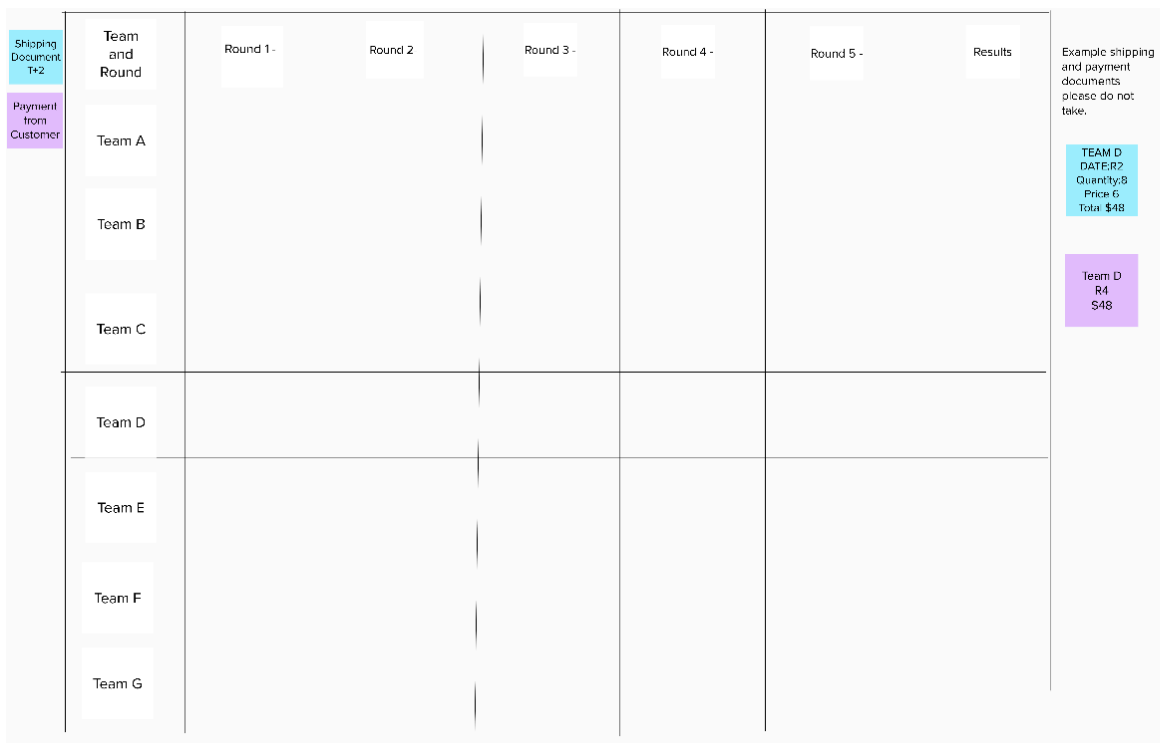

Customer Round 1-5

Figure 1: Customer Mural Whiteboard

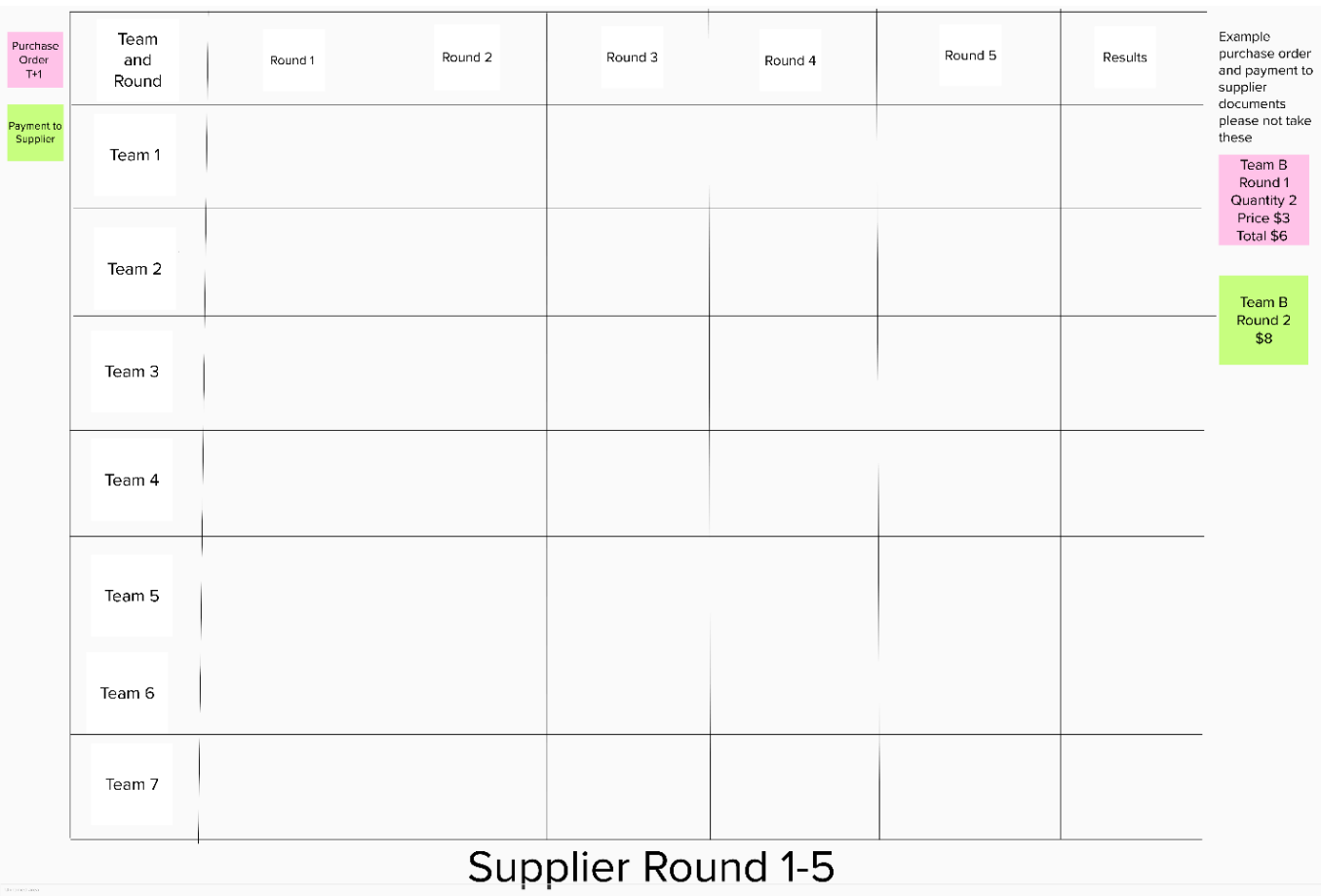

Figure 2: Supplier Mural Whiteboard 


\section{Issues in Information Systems}

Volume 22, Issue 4, pp. 180-190, 2021

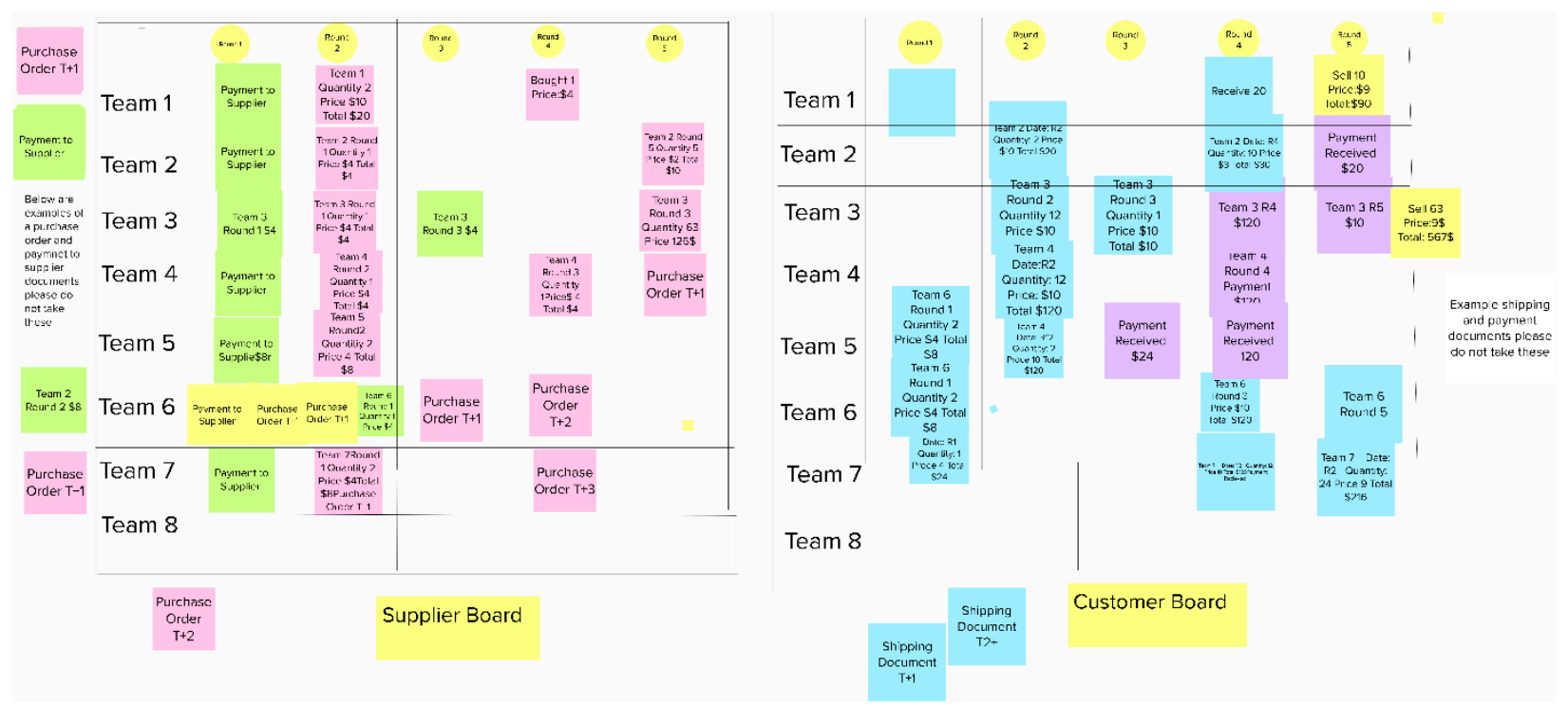

Figure 3: Completed Mural Whiteboards

\section{Methodology}

Two professors administered the teaching activities at two medium-sized public universities in the southeast, teaching Enterprise Resource Planning courses. The participants were junior and senior students majoring in business. The four classes met twice a week for an hour and fifteen minutes per class, virtually using Zoom. There were a hundred and seven students who participated in the study. Students were given a post-test to assess their knowledge of business processes and to assess other related learning activities that were administered. Before the course, the students had no business process management experience or training.

The game was administered at the beginning of the course during the second week of class. Before playing the game, students were provided lectures on key business processes in an organization to create a basic understanding of business process management and the various functional departments involved in the processes. Then, the game was played during one class period for a total of five rounds. The students were divided into teams comprising of four to five students each. The duration of each round was two minutes. During the game, students actively participated and asked several questions to the instructor by calling the instructor into their breakout room in Zoom.

After completing the game, one class period was devoted to drawing process diagrams on a virtual whiteboard in Zoom. The students were instructed to illustrate the process of how their team worked. The drawings were displayed through Zoom by each team sharing their screen. This activity allowed the students to demonstrate their understanding of business processes by explaining their team's drawing, seeing the other teams' drawings, and discussing the differences in the team drawings. The instructor provided feedback on how to correct mistakes and reinforce learning. The students were informed that everyone who participated in the game received the same grades and that there were no right or wrong diagrams.

Students watched an instructional video on how to create BP models using Microsoft Visio during the next class period. Then, students were asked to develop BP models in Visio as part of a graded assignment based 


\section{Issues in Information Systems}

Volume 22, Issue 4, pp. 180-190, 2021

on prior feedback on drawings. After the students received feedback on their Visio BP models, they were given a survey that consisted of two parts. The first part contained four multiple-choice questions related to procurement, fulfillment, inventory, and accounting to evaluate the students' understanding of BP concepts. The second part of the survey contained four questions identifying how the students perceived the learning activities administered with the paper game simulation. The perception questions were on a 7point Likert scale. The students were asked at the end of the survey to rank on a scale of 1 to 5, with 1 being most effective and 5 being least effective learning activities: class lecture, paper game, creating the drawings of the BP models, instructor feedback of the models and creating the BP models in Visio.

\section{Results}

The students performed well on the knowledge-based BP questions. The results are displayed in Table 1. The results show that ninety percent of the students understood the procurement process. Seventy-three percent understood the warehouse process. Sixty-one percent of the students understood the warehouse and accounting process relationship, and fifty-one percent understood the accounting process.

Table 1: Knowledge Question

\begin{tabular}{|l|l|}
\hline \multicolumn{1}{|c|}{ Knowledge Question } & Percent Correct \\
\hline $\begin{array}{l}\text { is the process of buying or acquiring the } \\
\text { materials used by the organization. }\end{array}$ & $90 \%$ \\
\hline $\begin{array}{l}\text { When a customer places an order, the must locate } \\
\text { the materials and prepare and send shipments to the customer. }\end{array}$ & $73 \%$ \\
\hline The materials shipped by vendor are received in & \\
\hline and the invoice sent by the vendor is & $61 \%$ \\
\hline $\begin{array}{l}\text { True or False: The Sales Department receives payment from } \\
\text { the customer. }\end{array}$ & $51 \%$ \\
\hline
\end{tabular}

Table 2 displays the students' perceptions of the learning activities used with the virtual paper game simulation. Thirty-one percent of the students chose playing the virtual paper game as having the highest learning impact. The second most effective learning activity was creating the BP models in Viso, and the third most effective learning activity was the class lecture. 
Table 2: Learning Activity Effectiveness

\begin{tabular}{|l|l|l|l|l|l|}
\hline \multicolumn{5}{|c|}{ Learning Activity Effectiveness } & \\
\hline $\begin{array}{l}\text { Please rank the following activities } \\
\text { in order of their effectiveness in } \\
\text { helping you lear BPM, with } 1 \\
\text { being the most effective and 5 being } \\
\text { the least effective. }\end{array}$ & 1 & 2 & 3 & 4 & 5 \\
\hline $\begin{array}{l}\text { Class Lecture Paper Game } \\
\text { Playing the }\end{array}$ & $25 \%$ & $20 \%$ & $10 \%$ & $16 \%$ & $21 \%$ \\
\hline Simulation & $71 \%$ & $18 \%$ & $12 \%$ & $21 \%$ & $13 \%$ \\
\hline Creating Drawings & $7 \%$ & $25 \%$ & $17 \%$ & $19 \%$ & $27 \%$ \\
\hline Instructor Feedback of Drawings & $9 \%$ & $15 \%$ & $36 \%$ & $19 \%$ & $15 \%$ \\
\hline Creating BP Models in Visio & $28 \%$ & $20 \%$ & $10 \%$ & $16 \%$ & $21 \%$ \\
\hline
\end{tabular}

Table 3 displays the results of the students' perceptions of playing the virtual paper game simulation. Eightyeight percent agreed that the paper game gave them a clear understanding of key business processes and how they are integrated into an organization. Ninety percent of the students agreed that the SAP Paper Game helped illustrate the BPM concepts discussed by the instructor in class. Eighty-six percent of students agreed that the SAP Paper Game was a worthwhile experience. Eighty-nine percent of students agreed that simulation games enhanced their learning. 
Table 3: Student Learning Perceptions from the Virtual Paper Game Simulation

\begin{tabular}{|c|c|c|c|c|c|c|c|}
\hline \multicolumn{8}{|c|}{ Student Learning Perceptions from the Virtual Paper Game Simulation } \\
\hline & $\begin{array}{l}\text { Strongly } \\
\text { Agree }\end{array}$ & Agree & $\begin{array}{l}\text { Somewhat } \\
\text { Agree }\end{array}$ & $\begin{array}{l}\text { Neither } \\
\text { Agree or } \\
\text { Disagree }\end{array}$ & $\begin{array}{l}\text { Somewhat } \\
\text { Disagree }\end{array}$ & Disagree & $\begin{array}{l}\text { Strongly } \\
\text { Disagree }\end{array}$ \\
\hline $\begin{array}{l}\text { The SAP paper game } \\
\text { gave me a clear } \\
\text { understanding of key } \\
\text { business processes and } \\
\text { how they are integrated } \\
\text { in an organization. }\end{array}$ & $12 \%$ & $58 \%$ & $18 \%$ & $6 \%$ & $3 \%$ & $2 \%$ & $0 \%$ \\
\hline $\begin{array}{l}\text { The SAP Paper Game } \\
\text { was helpful in } \\
\text { illustrating the BPM } \\
\text { concepts discussed by } \\
\text { the instructor in class. }\end{array}$ & $16 \%$ & $51 \%$ & $23 \%$ & $4 \%$ & $2 \%$ & $2 \%$ & $0 \%$ \\
\hline $\begin{array}{l}\text { The SAP Paper Game } \\
\text { was a worthwhile } \\
\text { experience. }\end{array}$ & $20 \%$ & $39 \%$ & $30 \%$ & $3 \%$ & $3 \%$ & $3 \%$ & $0 \%$ \\
\hline $\begin{array}{l}\text { In general, I believe } \\
\text { simulation games } \\
\text { enhance my learning. }\end{array}$ & $24 \%$ & $44 \%$ & $21 \%$ & $7 \%$ & $0 \%$ & $2 \%$ & $0 \%$ \\
\hline
\end{tabular}

\section{Limitations and recommendations for future research}

As with most research, there are limitations. First, this research was carried out during a pandemic. It is possible that the students' perceptions of the virtual paper game simulation could have been skewed because of their other online classes not being interactive. It would be interesting to repeat the virtual paper game simulation when higher education was not forced into a virtual learning environment. It is also important to note that only $51 \%$ of the students correctly answered the accounting question. It is possible that completing the paper game in person would result in a higher level of learning in regard to the accounting process.

Second, the two universities that this was applied to were both medium-sized public institutions. It would be interesting to see the virtual paper game administered at a different type of institution. Comparing the results between different types of universities would be interesting to see if similar levels of learner were reported and seen.

Last, we could only run five rounds during the virtual class period with the virtual paper game simulation. When this is administered in person, we were able to run ten rounds of the paper game. It would be interesting to run a class section with the paper game simulation in person and a class section with the virtual paper game and compare the learning results. 


\section{Issues in Information Systems}

Volume 22, Issue 4, pp. 180-190, 2021

\section{Conclusion}

Due to the growing demand for BPM knowledge and skills in industry, universities need to incorporate BPM into their curriculum. In addition, universities need to learn how to integrate engaging, active learning activities in a virtual environment while teaching complex topics such as BPM and ERP. In this paper, we present a virtual way to administer the paper game simulation. Overall, the students reported high levels of learning and high levels of business process knowledge.

\section{References}

Adelsberger, H. H., Bick, M. H., Kraus, U. F., \& Pawlowski, J. M. (1999). A simulation game approach for efficient education in enterprise resource planning systems. Proc. of ESM (Vol. 99, pp. 454460).

Auman, C. (2011). Using simulation games to increase student and instructor engagement. College Teaching, 59(4), 154-161. doi:10.1080/87567555.2011.602134

Baiyere, A., Salmela, H., \& Tapanainen, T. (2020). Digital transformation and the new logics of business process management. European Journal of Information Systems, 29(3), 238-259.

Bandara, W., Chand, D. R., Chircu, A. M., Hintringer, S., Karagiannis, D., Recker, J. C., \& Welke, R.J. (2010). Business process management education in academia: Status, challenges, and recommendations. Communications of the Association for Information Systems, 27, 743-776.

Bowen, J. A. (2012). Teaching naked: How moving technology out of your college classroom will improve student learning. John Wiley \& Sons.

Cronan, T. P., \& Douglas, D. E. (2012). A student ERP simulation game: A longitudinal study. Journal of Computer Information Systems, 53(1), 3-13.

Cronan, T. P., Douglas, D. E., Alnuaimi, O., \& Schmidt, P. J. (2011). Decision making in an integrated business process context: Learning using an ERP simulation game. Decision Sciences Journal of Innovative Education, 9(2), 227-234. doi:10.1111/j.1540-4609.2011.00303.x

Gredler, M. E. (2004). Games and simulations and their relationships to learning. In Handbook of research on educational communications and technology (Ch. 2, pp. 571-581).

Hartman, N. S., Watts, C. A., \& Treleven, M. D. (2013). Appreciating the complexity of project management execution: Using simulation in the classroom. Decision Sciences Journal of Innovative Education, 11(4), 323-334. doi:10.1111/dsji.12016

Hays, J. M. (2008). Trikes, cars, and the theory of constraints (TOC). Decision Sciences Journal of Innovative Education, 6(2), 349-354. doi:10.1111/j.1540-4609.2008.00179.x

Hough, J. (2012). The case of business simulations in higher education in South Africa. South African Journal of Higher Education, 26(5), 973-986.

Lean, J., Moizer, J., Towler, M., \& Abbey, C. (2006). Simulations and games use and barriers in higher 


\section{Issues in Information Systems}

Volume 22, Issue 4, pp. 180-190, 2021

education.

Leger, P. M. (2006). Using a simulation game approach to teach ERP concepts. Montreal: HEC Montreal, Groupe de recherche en systemes d'information.

Leger, P.M. (2015). Introduction to Business Process Management: The Paper Game, ERPsim Lab.

Leger, P. M., Charland, P., Feldstein, H., Robert, J., Babin, G., \& Lyle, D. (2011). Business simulation training in information technology education: Guidelines for new approaches in IT training. Journal of Information Technology Education: Research, 10(1), 39-53.

McKinsey \& Company. (2018). Unlocking Sussessin Digital Transformations. https://www.mckinsey.com/ /media/mckinsey/business\%20functions/organization/our\%20insigh ts/unlocking\%20success $\% 20 \mathrm{in} \% 20$ digital\%20transformations/unlocking-success-in-digitaltransformations.pdf? shouldIndex =false.

Newell, J. A. (2004, June). Survivor: A Method for Active Learning in the Classroom that Addresses Student Motivation. Proceedings of the American Society for Engineering Education.

Pridmore, J., \& Godin, J. (2018). Investigation of virtual teams and serious games, Journal of Computer Information Systems, DOI: 10.1080/08874417.2018.1443293.

Russ, T., \& Drury-Grogan, M. L. (2013). Assessing the Impact of a Business Communication Simulation on Students Self-Perceptions. Communication Quarterly, 61(5), 584-595. oi:10.1080/01463373.2013.822404

Salas, E., Wildman, J. L., \& Piccolo, R. F. (2009). Using simulation-based training to enhance management education. Academy of Management Learning \& Education, 8(4), 559-573. doi:10.5465/AMLE.2009.47785474

Saraswat, S. P., Anderson, D. M., \& Chircu, A. M. (2014). Teaching Business Process Management with Simulation in Graduate Business Programs: An Integrative Approach. Journal of Information Systems Education, 25(3).

Sarvepalli, A., \& Godin, J. (2017). Business Process Management in the classroom. Journal of Cases on Information Technology (JCIT), 19(2), 17-28.

Sheldon, L. (2011). The multiplayer classroom: Designing coursework as a game. Cengage Learning.

Smith-Daniels, D. E., \& Smith-Daniels, V. L. (2008). Trade-offs, biases, and uncertainty in project planning and execution: A problem-based simulation exercise. Decision Sciences Journal of Innovative Education, 6(2), 313-341. doi:10.1111/j.1540-4609.2008.00177.x

Zairi, M. (1997). Business process management: a boundaryless approach to modern competitiveness. Business process management journal. 